\title{
Volatility transmission of barley world price to the domestic market of Iran and the role of Iran Mercantile Exchange; an application of BEKK model
}

\author{
Mahmoud Daneshvar KakhKI*, Mohammad Mehdi FarsI ${ }^{\star *}$, \\ Behzad FaKarI $^{\star \star}$, Moustafa KojORI ${ }^{\star \star \star}$
}

DOI: $10.30682 / \mathrm{nm} 1903 \mathrm{~h}$

JEL codes: E31, Q11, Q18

\begin{abstract}
Barley is one of the main crops after wheat and rice. The importance of this product increases because it is an essential input in the livestock and poultry industries. The prices of input, which used in the livestock and poultry industries, faced fluctuations in recent years. Thus, in this study, the price fluctuation of barley in the Iran Mercantile Exchange, Iran domestic free market and World Market compared by applying the GARCH model. This model applied to monthly prices of barley from March 2009 to February 2017. Also, the volatility and shock transmission of barley price between these three markets analyzed by the BEKK model. The results showed that the price fluctuations of the domestic market are more than the global market. In addition, the shocks and volatilities of the world and Iran free market transmitted to the Iran Mercantile Exchange. Thus, the use of new financial instruments in the domestic free market is necessary.
\end{abstract}

Keywords: Barley, Fluctuation, GARCH, BEKK.

\section{Introduction}

In recent decades, globalization creates circumstances which agricultural markets become more connected to each other (Assef, 2016). In such condition, price volatility becoming an essential issue because price fluctuation in one market easily transmitted to the related markets and price volatility would intensify (Fakari et $a l ., 2016)$. In many countries, international and local markets linked to each other because of in- ternational trade. In recent years, global agricultural commodity price soared rapidly in 20072008 and then again in 2010-2011 and present a very volatile pattern (Hassouneh et al., 2017). The average unconditional volatility of international price in grain markets almost rose 80 percent, this price volatility usually transmitted to grain markets in developing countries (Ceballos et al., 2015). Price volatility has a drastic impact on some actors such as producers, consumers, investors, and government (Fakari et al., 2013).

* Professor of Agricultural Economics, Ferdowsi University of Mashhad, Iran.

** Ph.D. Student of Agricultural Economics, Ferdowsi University of Mashhad, Iran.

*** M.Sc. Graduated of agricultural Economics, Ferdowsi University of Mashhad, Iran.

Corresponing author:mm_farsi22@yahoo.com 
In fact, when the prices volatility of agricultural products increases, the producers, consumers and all the stakeholders in the food chain will become more vulnerable (Balcombe 2010). From producer's perspective, price volatility generates ambiguity about the difference between the actual and expected output price; therefore, producer's decision might change; in such condition, risk-averse farmers will adjust their cropping pattern to less volatile production activities and vice versa (Boere et al., 2015). Additionally, Price fluctuation also can generate a higher cost for importer and exporter because of irregularity in the agricultural market and inflation pressures (Lahiani et al., 2013). Understanding volatility transmission mechanism is essential for all the actors especially investor and government (Mensi et al., 2013). Investors need this sort of information for portfolio management to develop their investment strategies in each market and food market is vital for investors because of its tremendous profit (Jebabli et al., 2014). Policymakers also require this information to use proper price policy in order to manage the market and anticipate the future market irregularity (Jebabli et al., 2014); it is also essential to understand the reasons for price volatility and the potential cost of food price spike on poor consumers to design the policies for market intervention (Gouel 2013). In general, severe price volatility will reduce total welfare. However, in many markets, there are no situated mechanisms to circumvent price risks. Thus, the knowledge about the nature of price risks and identifying them in agricultural markets can reduce the destructive effects in developing countries and in the long-term, the fluctuations can be controlled (Aiezman and Pinto 2005).

Price volatility is more common in the agricultural commodity market because of seasonality, inelastic demand, production uncertainty, and perishability (Fakari et al., 2016). When a local agricultural commodity market linked strongly to a global market any price fluctuation in the global market can be transmitted directly to the domestic market. This kind of price volatility transmission is a more challenging issue for the developing countries; because lack of appropriate policy measures in these countries might lead to severe price volatility (Kornher et al., 2017). Therefore, policymakers try to prevent the volatility spillover from the international market to domestic markets through trade policy actions and creating agricultural commodity exchange (Lee et al., 2015).

In recent years, the development in the international agri-food markets affected by the significant price volatility (Matošková 2011). This raised concern about unexpected price volatility spillover to the domestics markets; so many studies conducted in this area to investigate the price volatility transmission. Some of this studies specified that price fluctuation in one market can be transmitted to related markets (Da Silveira and Mattos 2015; Sanjuan-Lopez and Dawson, 2017). On the other hand, several studies did not detect any apparent volatility spillover from the global agricultural commodity market to local market (Hernandez et al., 2014 and Gardebork et al., 2015)

Jörg and Gareis (2010) indicate that price volatility for different agricultural commodities anticipated remaining an important issue in the future; therefore, the national and international organization should design policy measures to control price volatility. Robles and Torero (2010) examined the price volatility transmission from the international market to domestic food market across four countries in South America; they also indicated that price volatility transmitted from global to local market of these countries. Wang and Garcia (2011) showed that there is a strong relationship between corn price volatility and the globalization phenomenon. They surveyed the influences of long-term structural changes on corn price volatility and structural changes in a flexible framework after a period of falling prices is very difficult. Beckman and Czudaj (2013) examined the volatility transmission in agricultural futures markets; they designated that with the increasing interdependence of global market, examination of the single future market is not suitable, so, the volatility spillover between various agricultural future markets should take into the consideration; because the response of each market to price volatility in international market can be different. The results provide evidence in favor of an existing short-run volatility 
spillover in the agricultural futures markets. Lee et al. (2015) examine the world price transmission and volatility spillover across six major Asian rice markets; and confirmed that change in the world price affects both price level of domestic markets and their conditional variance. Ceballos et al. (2015) examine the source of domestic food price volatility in several developing countries, this study conducted for major grain commodities to 41 domestic food products across 27 countries; they concluded that volatility transmission is more common when trade is large relative to domestic requirements. Fakari et al. (2016), investigated volatility spillover in Iran's meat market; their results showed that a mutual relationship between volatility in different parts of a meat market and price volatility in one market transmitted to related markets. Cinar (2018) focused on the Price volatility transmission in cereal markets; the results confirmed one-way volatility transmission from corn and barley market to the wheat market existed and price monitoring in livestock feed market can be a beneficial policy masseur. Cinar and Keskin (2018), specified that price volatility in poultry input markets (Energy and Soybean) have a significant impact on output volatility price; therefore, integrated policy strategy that includes poultry, energy and, feed market should design.

These studies revealed that price volatility transmission in the agricultural market is a vital issue. Because of the conduction of different risk management package, Price volatility transmission in different markets and different countries presented an ambiguous pattern; therefore, analyzing the impact of various policy masseur should take into consideration.

The subject of this study is to investigate the price volatility transmission from international barely markets to Iran free barely market and Iran mercantile exchange, and also the role of Iran Mercantile exchange in the management of barely price volatility transmission from international to Iran free market have been investigated.

Barley is a widely adaptable cereal, which grows well in dry weather conditions. It is more resistant to drought as compared to wheat. Thus, when the climate condition considered a limitation for grain production, barley can be a more productive commodity (FAO, 2004). The total production of barley in Iran is about 3.2 million tons, which are less than the requirement; thus, the deficiency compensated by import (Iran Ministry of Agriculture, 2015). As a matter of fact, in recent years Iran stands between the five major importer of barley; and in 2015 more than 29 percent of Iranian barley consumption is imported from international markets and this share experience an increasing trend since 2009 (AWNRC, 2017). On the other hand, increasing in the per capita consumption of meat cause an upturn in the barely demand as a main input of the poultry and livestock fees. Hence, volatility management in this market is very important for policymakers. The linkage between domestic and international market can be a source of price volatility in the barley domestic market, and a considerable share of imported product for covering the consumption might exacerbate the price volatility in domestic markets. Therefore, in this study, first, barley price fluctuations in the world market and Iran domestic market (including free market and Iran Mercantile Exchange) will compared. Then, price volatility transmission between these three markets will analyzed in order to evaluate the role of Iran Mercantile Exchange as a market, which established to manage the price risks; moreover, the necessity of trade policy conduction in barley market for price volatility transmission can discerned.

\section{Materials and method}

In this study, the price volatility of barley in the Iran Mercantile Exchange, Iran free market and the world market compared, and then volatility transmission between these three markets discussed. Monthly data from March 2009 to February 2017 used for this purpose. This period considered because of the data availability; moreover, this period includes the international price spike of 2010-2011, which might lead to interesting results. The prices of barley for Iran Mercantile Exchange and the free market is in Iranian Rial and are collected from Iran Mercantile Exchange and Iran Ministry of Agriculture respectively; we used U.S.D for world price of barley to avoid the effect of the exchange rate 
volatility on the world price. Since stakeholders decision accomplished base on the maker's prices, all the prices considered in a nominal term. Moreover, in order to avoid the impact of different monetary unites all the variables transformed into logarithmic form.

In order to compare the price volatility of barley in these three markets, at first, the series must tested for the presence of a unit root. For this purpose, the Augmented Dickey-Fuller (ADF) test is applied. If the series has a unit root, differencing must continue until the series become stationary. Then the Lagrange Multiple Test (LM-Test) applied to check the presence of Autoregressive Conditional Heteroscedasticity (ARCH) effect. If the ARCH effect obtained, the volatility will modeled using the ARCH/ GARCH models and the results of three price series compared with each other. To investigate the price volatility transmission different Multivariate-GARCH model is available; however, since the BEKK could be used to capture the price volatility and shock transmission at the same time (Caporin and McAleer, 2010), thus, this model is applied to data in this study to investigate the price volatility and shock transmission between different markets.

In economic terms, the average of price volatility transmission effects between several markets refers to the fact that the price in a specific market, not only is affected by its own previous volatility but also is affected by price fluctuations in other related markets. In the long-run, testing the average of price volatility spillover effects has an important role to indicate that whether price volatility is important and if it could help in to predict future trends (Baba et al., 1991). The simplest way to calculate the fluctuations is using the previous period data. The previous volatilities can easily be calculated by variance (or standard error) and it is a suitable method to predict volatility for all the future courses. Conventional model to measure the input price volatility based on the option contracts and using previous mean-variance (or standard error). Available evidence indicates development in forecasting the future volatility, which suggests models that are more complicated forecast future. Previous volatilities are useful paragons to compare the forecasting ability of complicated models (Brooks 2008).

\subsection{ARCH and GARCH methods}

There is an important assumption in the classic econometric method that says the residual term has a constant variance during the time; however, sometimes the time series have been faced a drastic volatility in some periods and on the other hand showed an insignificant fluctuation in another period of time. The assumption of constant variance for the residual term in this condition is not logical and classic econometric model cannot used. In ARCH and GARCH methods, the Conditional Heteroscedasticity is dependent on its previous values and an increase in the variance of the residual term in current can cause an increase in conditional variance in future (Bollerslev et al., 1988). The ARCH model introduced by Engle (1982) and after that, Bollerslev (1986) presented the GARCH model. In this model, two equations estimated for the mean and variance to model the volatilities. The basic equation for $\mathrm{GARCH}(\mathrm{q}, \mathrm{p})$ is presented in equation (1) and (2).

$$
\begin{aligned}
& Y_{t}=\mu_{t}+\sigma_{t} Z_{t}, i_{t \sim} N I D(0,1) \\
& \mu_{t}=a+\sum_{i=1}^{k} b_{i} X_{i, t} \\
& \sigma_{t}^{2}=\alpha_{0}+\alpha \alpha_{1} \varepsilon_{t-1}^{2}+\ldots+\alpha_{\mathrm{q}} \varepsilon_{t-q}^{2}+\beta_{1} \sigma_{t-1}^{2} \ldots \\
& +\beta_{p} \sigma_{t-p}^{2}=\alpha_{0}+\sum_{i=1}^{q} \alpha_{i} \varepsilon_{t-i}^{2}+\sum_{i=1}^{p} \beta_{i} \sigma_{t-i}^{2} \\
& \varepsilon_{t} \sim \operatorname{NID}\left(0, H_{t}\right)
\end{aligned}
$$

In the first equation, $\mathrm{Y}_{\mathrm{t}}$ is conditional mean which depends on explanatory variables that are shown by $X_{i, t}$ and $Z_{t}$ is the residual term. The second equation is the variance equation and the coefficients should be estimated.

\subsection{BEKK model}

Recently much attention has focused on how news from one market affects the volatility process of the relevant markets. In this study, we analyze the volatility transmission effect be- 
tween three markets by using a multivariate framework of the BEKK parameterization (Engle and Kroner 1995). In this model, the variance-covariance matrix of equations depends on the squares and cross products of innovation $\varepsilon_{t}$, which is derived from the mean equation that is presented in equation (3):

$\mathrm{R}_{\mathrm{t}}=\mu_{\mathrm{t}}+\varepsilon_{\mathrm{t}} \quad \varepsilon_{\mathrm{t}} \Omega_{\mathrm{t}-1} \sim \mathrm{N}\left(0, \mathrm{H}_{\mathrm{t}}\right)$

Where $R_{t}$ is the $\mathrm{n} \times 1$ vector of returns at time $t$ for each market. The $\mathrm{n} \times 1$ vector of random errors, $\varepsilon_{t}$, represents the innovation for each market at time $t$ with its corresponding $\mathrm{n} \times \mathrm{n}$ conditional variance-covariance matrix $\mathrm{H}_{t}$ and the market information available at time $\mathrm{t}-1$ is represented by $\Omega_{\mathrm{t}-1}$.

This multivariate structure facilitates the measurement of the effects of innovations in the mean returns of one market on its own lagged returns and those of the lagged returns of the other markets. The standard BEKK parameterization for the multivariate GARCH model written as:

$$
H_{t}=C^{\prime} C+\alpha^{\prime} \varepsilon_{t-1} \varepsilon_{t-1}^{\prime} \alpha+\beta^{\prime} H_{t-j} \beta
$$

As presented in equation (4), $\mathrm{H}_{\mathrm{t}}$ is a $\mathrm{n} \times \mathrm{n}$ matrix of conditional variance-covariance at time $t$, and $C$ is a $n \times n$ lower triangular matrix, which contains constant terms. $\alpha$ and $\beta$ are $n \times n$ squared matrixes of coefficients and measure the extent to «which conditional variances are correlated previous squared errors» and "which current levels of conditional variances are related to previous conditional variances». As introduced in the last paragraph, $\mathrm{C}$ is the matrix of the constant term. $\alpha$ is a $n \times n$ matrix which shows the $\mathrm{ARCH}$ effects. Therefore, the coefficients in this matrix indicate the effects of previous price shocks. The elements of the main diagonal of this matrix $\left(\alpha_{\mathrm{ii}}\right)$ indicate the ARCH effects of the market $\mathrm{i}$ on itself and other elements $\left(\alpha_{i j}\right)$ represent the effects of transmission of price shocks from market $i$ to j. $\beta$ is a $n \times n$ matrix which shows the GARCH effects. Therefore, the coefficients in this matrix indicate the effects of previous price fluctuations. The elements of the main diagonal of this matrix $\left(\beta_{\mathrm{ii}}\right)$ indicate the GARCH effects of the market $i$ on itself (the effect of the previous price volatilities of market $i$ on market i) and other elements $\left(\beta_{\mathrm{ij}}\right)$ represent the effects of transmission of price volatilities from market $i$ to $j$.

The presented BEKK model analyzes the effects of shocks and volatilities of several markets on each other, which can be symmetric or asymmetric. The Maximum Likelihood (ML) method applied to estimate BEKK model.

\section{Results}

In this study, at first, the volatilities of barley price in three markets compared. Table 1 shows some of the statistical characters of each market.

As Statistics reported in Table 1, mean of barely price in Iran mercantile exchange is less

Table 1 - Statistics of barley price.

\begin{tabular}{|l|c|c|c|}
\hline Statistics & $\begin{array}{c}\text { Barley price in Iran } \\
\text { Mercantile Exchange } \\
\text { (Rial per Kg) }\end{array}$ & $\begin{array}{c}\text { Barley price in Iran } \\
\text { free market } \\
\text { (Rial per Kg) }\end{array}$ & $\begin{array}{c}\text { Barley price in the } \\
\text { World market } \\
\text { (U.S.D per Kg) }\end{array}$ \\
\hline Mean & 5938.2 & 6075.3 & 0.17 \\
Maximum & 9797 & 9731 & 0.26 \\
Minimum & 1737 & 1610 & 0.1 \\
Standard deviation & 2634 & 2612 & 0.04 \\
\hline \multicolumn{3}{|c|}{ First Difference } \\
\hline Skewness & 1.68 & 0.16 & 0.35 \\
Kurtosis & 10.69 & 14.66 & 5.23 \\
Jarque-Bera & 279 & 539 & 21.73 \\
\multicolumn{4}{|c|}{$[0.0]$} \\
\hline
\end{tabular}

Source: Research Findings; P-values indicated in []. 
than the mean of price in Iran free market, because most of the transaction in the IME conducted by major importers. Therefore, it anticipated that IME take effect of world market more than the Iran free Market. Moreover, since the standard deviation in IME and Iran free Markets are almost the same it expected that these markets showed the same volatility pattern. The Jarque-Bera statistics showed that none of variables has a normal distribution.

According to the material and method, time series tested for the presence of unit root. Table 2 shows the results of Augmented Dickey-Fuller (ADF) tests for each series.

Due to the results in Table 2, all series are stationary at $1^{\text {st }}$ difference level. After that, the Lagrange Multiplier (LM) test applied to investigate the ARCH effects.

As Table 3 shows, there are ARCH effects in the price series of all three markets at $1^{\text {st }}$ difference level. Therefore, the ARCH/GARCH methods should used to model these series.
Table 4 shows the results of estimation of the mean and variance equations for every three markets. The diagram of the volatility of barley price at a $1^{\text {st }}$ difference level in the markets extracted from these equations.

According to Figure 1, volatility of barley price at $1^{\text {st }}$ difference level in Iran free market is more than Iran Mercantile Exchange and both of them show more fluctuation than the world market; because the main part of the transacted barley in Iran Mercantile Exchange is imported; therefore the exchange rate volatility may affect the barley price. In addition, Figure 1 shows that volatility in Iran free market is more than world market, which indicates that Iran Mercantile Exchange is not able to create a suitable hedging for volatility spillover for the free market. However, world price is calculated based on the average of the main world's stock exchanges and in this condition, fluctuations imply a moderate pattern. Also, in most stock exchanges of the world, futures trading takes

Table 2 - Results of ADF and PP tests for each market.

\begin{tabular}{|l|c|c|c|}
\hline \multirow{2}{*}{ Variable } & \multicolumn{2}{|c|}{ Augmented Dickey-Fuller (ADF) test } & \\
\cline { 2 - 4 } & $\begin{array}{c}\text { Estimated } t \text { value } \\
\text { in the level }\end{array}$ & $\begin{array}{c}\text { Estimated } \text { value in } \\
\text { the first difference }\end{array}$ & t-statistic for 5\% \\
\hline Barley price in Iran Mercantile Exchange & -1.47 & -5.68 & -2.89 \\
\hline Barley price in Iran free market & -1.92 & -7.19 & -2.89 \\
\hline Barley price in World market & -1.69 & $15.42-$ & -2.89 \\
\hline
\end{tabular}

Source: Research Findings.

Table 3 - Results of LM-test for barley price volatility at $1^{\text {st }}$ difference level.

\begin{tabular}{|l|c|c|c|c|}
\hline Variable & F-Statistic & Probability & $N \times R^{2}$ & Probability \\
\hline Barley price in Iran Mercantile Exchange & 3.53 & 0.00 & 42.05 & 0.00 \\
\hline Barley price in Iran free market & 6.7 & 0.01 & 6.4 & 0.01 \\
\hline Barley price in World market & 2.8 & 0.04 & 8.2 & 0.04 \\
\hline
\end{tabular}

Source: Research Findings.

Table 4 - Mean and variance equations for barley price volatility at $1^{\text {st }}$ difference level.

\begin{tabular}{|l|c|c|}
\hline Variable & Mean equation & Variance equation \\
\hline Barley price in Iran Mercantile Exchange & $\mathrm{AR}(2), \mathrm{MA}(2)$ & $\mathrm{ARCH}(1)$ \\
\hline Barley price in Iran free market & $\mathrm{AR}(1), \mathrm{MA}(2)$ & $\mathrm{GARCH}(1,1)$ \\
\hline Barley price in the World market & $\mathrm{AR}(1)$ & $\mathrm{GARCH}(1,1)$ \\
\hline
\end{tabular}

Source: Research Findings. 
Figure 1 - The volatility of barley price at $1^{\text {st }}$ differenced level in Iran Mercantile Exchange, Iran free market, and World market respectively.

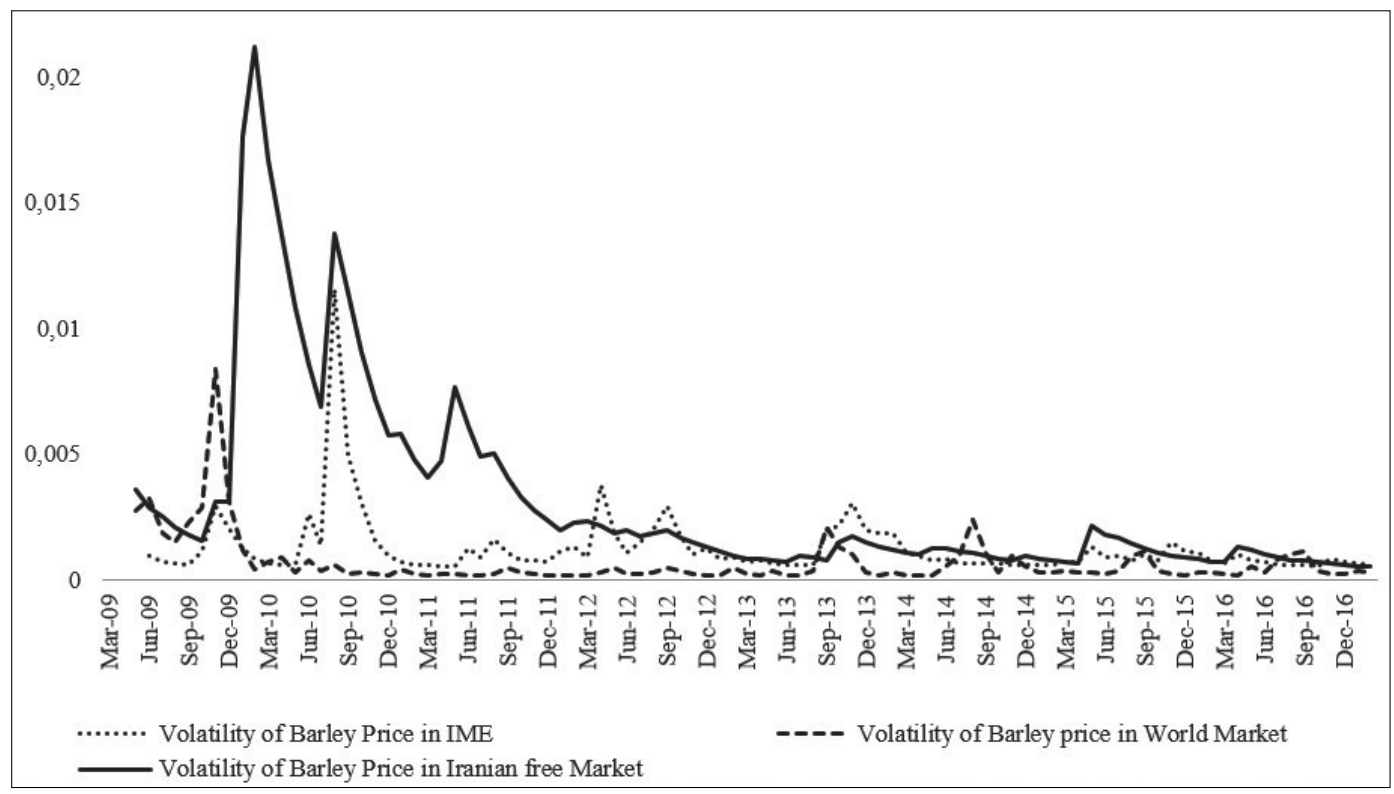

place for barley and this will reduce price volatility.

Price volatility is dependent on the market structure of each commodities, in fact, market with a higher price volatility may include a large number of small producers a weak market power (Fakari et al., 2016) . This condition absolutely matched to Iran free market; where a large number of framers try to sell their products with different strategies, thus they have to face with the volatile prices. On the other hand, Iran Mercantile exchange contained a few large importer, which can agreed on the similar strategies and build a strong market power; therefore, they experienced a moderate price volatility in compare to the Iran free market.

In this section, the transmission of shocks and volatilities between markets analyzed. BEKK model used for this purpose and the results of the estimation reported in Table 5.

In Table 5, the volatility of barley prices at $1^{\text {st }}$ difference level in Iran Mercantile Exchange, numbers 1, 2 and 3 respectively shows the world market and Iran free market. For example, $\alpha(2,1)$ represents transmitted shocks from world market to Iran Mercantile Exchange. As mentioned in the Materials and Methods section, the parameter $\mathrm{C}$ represents the intercept and is not involved in the interpretation. The parameter " $\alpha$ " represents the shock transmission of the internal and external markets. The results in Table 5 indicate that most of the significant coefficients are for the internal market which shows that the markets are severely affected by the shocks created in themselves $(\alpha(1,1), \alpha(2,2), \alpha(3,3))$. Coefficients also indicate that changes in barley price in Iran Mercantile Exchange react to shocks from the world market; however, it impacts is not considerable $(\alpha(2,1))$. Moreover, price shocks in a world market transmitted to Iran free market but then again the impact is not tangible. In domestic markets, it can be concluded that the free market shocks have a significant and strong effect on Iran Mercantile Exchange, but the shocks of Iran Mercantile Exchange don't have significant effects on price changes in the free market $(\alpha(1,3), \alpha(3,1))$.

Table 5 shows interesting results concerning the transmission of barley price fluctuations. As the transmission of shocks in the markets, it is cleared that the most significant coefficients 
Table 5 - BEKK model estimation results.

\begin{tabular}{|c|c|c|c|c|c|c|c|}
\hline Parameter & Coefficient & $\begin{array}{c}\text { Standard } \\
\text { Error }\end{array}$ & Probability & Parameter & Coefficient & $\begin{array}{c}\text { Standard } \\
\text { Error }\end{array}$ & Probability \\
\hline $\mathrm{c}(1,1)$ & 0.007 & 0.005 & 0.12 & $\alpha(3,1)$ & 0.7 & 0.12 & 0.00 \\
\hline $\mathrm{c}(2,1)$ & 0.005 & 0.008 & 0.6 & $\alpha(3,2)$ & -0.14 & 0.87 & 0.98 \\
\hline $\mathrm{c}(2,2)$ & 0.013 & 0.004 & 0.11 & $\alpha(3,3)$ & 1.03 & 0.12 & 0.00 \\
\hline $\mathrm{c}(3,1)$ & -0.008 & 0.005 & 0.11 & $\beta(1,1)$ & 0.66 & 0.15 & 0.00 \\
\hline $\mathrm{c}(3,2)$ & 0.006 & 0.008 & 0.43 & $\beta(1,2)$ & -0.003 & 0.07 & 0.00 \\
\hline $\mathrm{c}(3,3)$ & 0.0008 & 0.008 & 0.99 & $\beta(1,3)$ & 0.47 & 0.18 & 0.00 \\
\hline$\alpha(1,1)$ & 0.36 & 0.1 & 0.00 & $\beta(2,1)$ & 0.03 & 0.03 & 0.03 \\
\hline$\alpha(1,2)$ & 0.11 & 0.08 & 0.17 & $\beta(2,2)$ & -0.2 & 0.08 & 0.02 \\
\hline$\alpha(1,3)$ & 0.002 & 0.09 & 0.98 & $\beta(2,3)$ & -0.006 & 0.03 & 0.8 \\
\hline$\alpha(2,1)$ & 0.1 & 0.03 & 0.001 & $\beta(3,1)$ & 0.77 & 0.11 & 0.00 \\
\hline$\alpha(2,2)$ & 0.98 & 0.08 & 0.00 & $\beta(3,2)$ & -0.33 & 0.07 & 0.13 \\
\hline$\alpha(2,3)$ & 0.002 & 0.003 & 0.93 & $\beta(3,3)$ & 0.42 & 0.2 & 0.09 \\
\hline
\end{tabular}

Source: Research Findings.

for volatility transmission are internal $(\beta(1,1)$, $\beta(2,2), \beta(3,3))$. There is a significant transmission of world price volatility to Iran Mercantile Exchange; however, price fluctuation is not transmitted to Iran free market. The coefficients indicated that price volatility from Iran free market is transmitted to Iran Mercantile Exchange; on the other hand, price volatility from Iran Mercantile Exchange doesn't have a significant impact on price fluctuation in Iran free market $(\beta(3,1), \beta(1,2))$.

Based on the results, the international barley market is not affected by price shocks an volatility; because Iran does not play a vital role in the international barley market as an importer or exporter. Between the two parallel barely market in Iran, it seems that Iran Mercantile Exchange have a weak market power because price shock and volatility in both international and Iran free market have a considerable impact on it price shocks and volatilities. On the other hand, Iran Free Market present a significant price fluctuation, which it can be caused by a large number of the stakeholders. Moreover, these results specify that Iran Free Market may be possessing stronger market power relative to Iran Mercantile Exchange. These results are in line with the result of Assefa (2016).
BEKK Diagnosis and validity tests presented in table 6 . According to the results of the Jarque-Bera test, Error term of the BEKK model is normally distributed and LM tests indicated that the ARCH effect is not existed in the error term. Moreover, all the goodness of fit such as the log likelihood, Akaike and Schwarz criterion information values are optimal. Therefore, the estimation BEKK GARCH model is valid and results are reliable.

\section{Findings and Discussion}

Barely is a vital agricultural input in livestock production; in fact, more than 90 percent of barley production and import utilized as a livestock production input and role of this input remained sustainable in the last decade (Mashayekhi et al., 2005; WFP, 2016). Because of the important role of barely in livestock feed market and a considerable share of international trade in providing this input, price volatility in the price of this input in the International market might be transmitted to livestock markets and the producers and consumers welfare will affect (Cinar, 2018).

Iran Agricultural Commodity Exchange established to prevent the price volatility and shock transmission and barely known as the second 
Table 6 - BEKK Validity tests.

\begin{tabular}{|c|c|c|c|c|}
\hline Statistics & $\begin{array}{l}\text { Barley price in } \\
\text { Iran Mercantile }\end{array}$ & $\begin{array}{l}\text { Barley price in } \\
\text { Iran free }\end{array}$ & $\begin{array}{c}\text { Barley price in the } \\
\text { World market }\end{array}$ & Full Model \\
\hline \multicolumn{5}{|c|}{ Normality Test } \\
\hline Skewness & $\begin{array}{c}0.28 \\
{[0.33]}\end{array}$ & $\begin{array}{c}0.34 \\
{[0.17]}\end{array}$ & $\begin{array}{c}0.22 \\
{[0.45]}\end{array}$ & $\begin{array}{c}0.25 \\
{[0.38]}\end{array}$ \\
\hline Kurtosis & $\begin{array}{c}3.1 \\
{[0.84]}\end{array}$ & $\begin{array}{c}3.13 \\
{[0.66]}\end{array}$ & $\begin{array}{c}3.01 \\
{[0.97]}\end{array}$ & $\begin{array}{c}3.07 \\
{[0.91]}\end{array}$ \\
\hline Jarque-Bera & $\begin{array}{c}0.98 \\
{[0.41]}\end{array}$ & $\begin{array}{c}1.46 \\
{[0.33]}\end{array}$ & $\begin{array}{c}0.56 \\
{[0.55]}\end{array}$ & $\begin{array}{c}0.77 \\
{[0.47]}\end{array}$ \\
\hline \multicolumn{5}{|c|}{ LM test for ARCH residuals } \\
\hline $\operatorname{LM}(5)$ & $\begin{array}{l}-0.16 \\
{[0.13]}\end{array}$ & $\begin{array}{l}-0.06 \\
{[0.54]}\end{array}$ & $\begin{array}{l}-0.18 \\
{[0.13]}\end{array}$ & $\begin{array}{c}4.8 \\
{[0.85]}\end{array}$ \\
\hline $\mathrm{LM}(10)$ & $\begin{array}{l}-0.11 \\
{[0.28]}\end{array}$ & $\begin{array}{l}-0.12 \\
{[0.23]}\end{array}$ & $\begin{array}{l}-0.006 \\
{[0.95]}\end{array}$ & $\begin{array}{c}5.1 \\
{[0.82]}\end{array}$ \\
\hline \multicolumn{5}{|c|}{ BEKK Goodness of Fit } \\
\hline Log of likelihood & & & & 580.7 \\
\hline Akaike info criterion & & & & -11.91 \\
\hline Schwarz criterion & & & & -11.50 \\
\hline
\end{tabular}

important commodity in the market. However, the role of this market in the whole transaction is not noteworthy; in 2015, less than a percent of the total barley traded in this market (Chizari and Shirzad, 2017).

In this study, the price volatility of barley in three markets, Iran Mercantile Exchange, Iran free market and world market, analyzed and compared. Results showed that price volatility in Iran free market is more than other markets. The results indicated that the price volatility in domestic markets is more than world market which designates there is no suitable price policy or trade strategy in order to manage the price volatility. To reduce the price volatility developing a well-organized spot market with transparency and efficiency should be the first goal of the government and subsequently, proper infrastructure should originate by policymakers to transfer the transactions to the parallel market (Sehgal et al., 2012). In addition, the transmission of shocks and price volatility between three markets analyzed. The results of this section indicated that global price shocks and volatilities only have a significant effect on Iran Mercantile Exchange.
The results of BEKK model estimation also presented that shocks and volatilities of barley price in Iran free market have a significant effect on prices of Iran Mercantile Exchange.

According to the results, Iran Mercantile Exchange presents a more stable price and moderate price fluctuation in compare to Iran free market; this result is in line with the result of a Chizari and Shirzad (2017). Based on these results it is suggested that government introduce some incentives for producers and consumers to transmit their transaction in Mercantile Exchange; because the price pattern is more predictable in this market. Furthermore, they should purpose financial instruments such as futures and options contract that reduce the price volatility and shocks. These instruments help to control and decrease the shocks and volatilities of price by creating a hedge against fluctuations. Aside from these financial instruments, the government should work on the public awareness between all the stakeholders of this market to consider the IME as a better place for their transactions. Moreover, the development of regional IME in the important livestock production re- 
gions can be an effective method to reduce the price volatility and transaction costs (Kornher $e t$ al., 2017).

On the other hand, price in the global market showed a more stable pattern in compare to domestic markets; thus, government should design a flexible trade strategy to take advantage of this opportunity for decreasing the price volatility in domestic markets. Moreover, a price monitoring system should designed in order to inform the government about the global price movement and volatility to modify the trading strategy based on the different situation. Finally, Cinar (2018) recommended that the government should be designed a livestock and agricultural policy as a whole; however, where domestic markets are heavily dependent on international markets, agricultural, livestock, and trade policy should be designed as a whole.

\section{References}

Aiezman A. and Pinto B., 2005. Managing Economic Volatility and Crisis. A Practitioners. New York: Cambridge University Press, World Bank.

Apergis N. and Rezitis A., 2011. Food Price Volatility and Macroeconomic Factors: Evidence from GARCH and GARCH-X Estimates. Agricultural and Applied Economics, 43(1): 95-110.

Assefa T.T., 2016. The Transmission and Management of Price Volatility in Food Supply Chains. $\mathrm{PhD}$ thesis, Wageningen University, Wageningen.

AWNRC, 2017. Food Security Report, Iran Chamber of commerce, industry, mine and agriculture.

Baba Y., Engle R.F., Kraft D., Kroner K.F., 1991. Multivariate simultaneous generalized ARCH. The University of California and San Diego: Department of Economics, Discussion Paper.

Balcombe K., 2010. The Nature and Determinants of Volatility in Agricultural Prices: An Empirical Study from 1962-2008, MPRA Paper No. 24819.

Beckmann J. and Czudaj R., 2014. Volatility Transmission in Agricultural Futures Markets. Economic Modelling, 36: 541-546.

Boere E., Peerlings J., Reinhard S., Kuhlman T. and Heijman W., 2015. Effect of Output Price Volatility on Agricultural Land Use. New Medit, 3/2015.

Bollerslev T., 1986. Generalized autoregressive conditional heteroskedasticity. Federal Reserve Bank of Kansas City Economic Review, 79, 27-38; Journal of Econometrics, 31: 307-327.
Bollerslev T., Engle R.F. and Wooldridge J.M., 1988. A capital asset pricing model with time-varying covariances. The Journal of Political Economy, 96: 116-131.

Brooks C., 2008. Introductory Econometrics for Finance. Cambridge: Cambridge University Press, $2^{\text {nd }}$ ed., ISBN: 9780521694681.

Caporin M., McAleer M., 2010. Do we really need both BEKK and DCC? A tale of two multivariate GARCH Models, Kier discussion paper series, Kyoto Institute of Economics research.

Ceballos F., Hernandez M.A., Minot N. and Robles M., 2015. Grain Price and Volatility Transmission from International to Domestic Markets in Developing Countries. FPRI Discussion Paper 01472, October 2015.

Chizari A.H., Shirzad S., 2017. Investigation on Risk and Price Relationship between Agriculture Commodity Exchange and Traditional Market for Livestock Feed. International Journal of Management and Applied Science, 3(3), Mar 2017.

Cinar G., 2018. Price volatility transmission among cereal markets. The evidence for Turkey. New Medit, 3/2018, DOI: $10.30682 / \mathrm{nm} 1803 \mathrm{~h}$.

Cinar G., Keskin B., 2018. The spillover effect of imported inputs on boiler prices in Turkey. New Medit, 1/2018, DOI: $10.30682 / \mathrm{nm} 1801 \mathrm{~d}$.

Da Silveira R.D.F. and Mattos F.L., 2015. Price and Volatility Transmission in Livestock and Grain Markets: Examining the Effect of Increasing Ethanol Production Across Countries, Selected paper prepared for presentation at 2015 Agricultural \& Applied Economics Association and Western Agricultural Economics Association Annual Meeting, San Francisco, CA, July 26-28, 2015.

Engle R.F., 1982. Autoregressive conditional heteroscedasticity with estimates of the variance of UK inflation. Econometrica, 50: 987-1008.

Engle R.F. and Kroner K.F., 1995. Multivariate simultaneous generalized ARCH. Econometric Theory, 11: 122-150.

Fakari B., Farsi Aliabadi M.M. and Kojori M., 2013. Determining fluctuations and cycles of corn price in Iran. Agric. Econ. - CZECH, 59(8): 373-380.

Fakari B., Farsi Aliabadi M.M., Mahmoudi H. and Kojori M., 2016. Volatility Spillover and Price Shocks in Iran's Meat Market. Custos e @gronegócio online, 12(2), Apr/Jun 2016.

FAO, 2004. Barley: Post-Harvest Operations. The Central Research Institute for Field Crops, Ulus, Ankara, Turkey.

Gardebroek C., Hernandez M.A. and Robles M., 2016. Market Interdependence and Volatility Trans- 
mission among Major Crops. Agricultural Economics, 47(2): 141-155.

Gouel C., 2013. Optimal food price stabilization policy. European Economic Review, 57: 118-134.

Hassouneh I., Serra T., Bojnec S. and Gil J.M., 2016. Modeling price transmission and volatility spillover in the Slovenian wheat market. Applied Economics, 49(41): 4116-4126.

Jebabli I., Arouri M. and Teulon F., 2014. On the effects of world stock market and oil price shocks on food prices: An empirical investigation based on TVP-VAR models with stochastic volatility. Ipag Working Paper, 2014-209, http://www.ipag.fr/fr/ accueil/la-recherche/publications-WP.html.

Jörg M. and Gareis. J., 2010. Commodity price volatility: causes and impact on low-income countries, Paper prepared for the conference on "Impacts, Responses \& initial lessons of the financial crises for low-income countries", Danish Institute for International Studies, Copenhagen, 14-15 October 2010.

Kornher L., Kalkuhl M. and Mujahid I., 2017. Food price volatility in developing countries - the role of trade policies and storage. FOODSECURE Working paper no. 57, February 2017.

Lahiani A., Nguyne D.K. and Vo T., 2013. Understanding Return and Volatility Spillovers Among Major Agricultural Commodities. Journal of Applied Business Research, Nov/Dec 2013.

Lee J., Glenn H. and Valera A., 2015. Price Transmission and Volatility Spillovers in Asian Rice Markets: Evidence from MGARCH and Panel GARCH Models. The International Trade Journal, 30(1): $1-20$.

Mashayekhil S., Keshava Reddy T.R. and Achoth L., 2005. Relative performance of barley in Iran and
India and its role in livestock industry. Cuban Journal of Agricultural Science, 39(1), 2005.

Matošková D., 2011. Volatility of agrarian markets aimed at the price development. Agric. Econ. CZECH, 57(1): 34-40.

Mensi W., Beljid M., Boubaker A. and Managi S., 2013. Correlations and Volatility spillovers across commodity and stock markets: Linking energies, food, and gold. Economic Modelling, 32: 15-22.

Ministry of Agriculture of Iran, 2008-2015.

Rapsomanikis G., 2011. Price Transmission and Volatility Spillovers in Food Markets. In Safeguarding Food Security in Volatile Global Markets, Ed. A. Prakash, Rome: FAO, pp. 149-186.

Robles M. and Torero M., 2010. Understanding the Impact of High Food Prices in Latin America. Economia, 10(2): 117-164.

Sanjuan-Lopez A.I., and Dawson P.J., 2017. Volatility Effects of Index Trading and Spillovers on US Agricultural Futures Markets: A Multivariate GARCH Approach. Journal of Agricultural Economics, 68(3).

Sehgal S., Rajput N., Kumar Dua R., 2012. Futures Trading and Spot Market Volatility: Evidence from Indian Commodity Markets. Asian Journal of Finance \& Accounting, 4(2).

Wang X. and Garcia Ph., 2011. Forecasting Corn Futures Volatility in the Presence of Long Memory, Seasonality and Structural Change. Selected Paper prepared for presentation at the Agricultural \& Applied Economics Association's 2011 AAEA \& NAREA Joint Annual Meeting, Pittsburgh, Pennsylvania, July 24-26.

WFP, 2016. Food and Nutrition Security in Iran, World Food Program. 